石油技術協会誌 第 73 巻 第 5 号（平成 20 年 9 月） $356 \sim 360$ 頁 Journal of the Japanese Association for Petroleum Technology Vol. 73, No. 5 (Sept., 2008) pp. 356 360

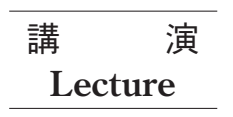

磐城沖プラットフォームの 3 重管撤去*

$$
\text { 西 脇 一 仁** }
$$

(Received July 17, 2008 ; accepted September 11, 2008)

\title{
The removal operation of conductor pipes on Iwaki-oki offshore platform
}

\author{
Kazuhito Nishiwaki
}

\begin{abstract}
Iwaki-oki oil exploration commissioned Teikoku oil to remove the conductor pipe and abandon wells on Iwaki-oki offshore platform. The removal operation of conductor pipes is the first time for us, therefore we adopted the service company operational skills which is the removal operation of conductor pipes on the North West Hutton offshore platform.

From an environmental point of view, we made a plan to wash out shells from the conductor pipe during the operation.

After trial and error for establishing the way of operation, we completed to remove all pipes from 15 gas extension wells. As a result, we can shorten the period of operation by 23 days.
\end{abstract}

Keywords : Cut \& recover 3 casings at one time, well abandonment, offshore platform, environment, safety job procedure

\section{3 重管撤去方法の決定まで}

平成 17 年 3 月 16 日に行われた，新日本製鐵株による 「概念設計エンジニアリング業務の最終報告会」の段階で は，3 重管撤去作業はプラットフォーム撤去工事が行われ る折りに，その工事の一環として行われる方針であった。 報告会においては, 3 重管の切断工法としてアブレッシブ ウォータージェットカッティングと爆薬切断の 2 つの工法 が紹介されていた。

その後の議論で, プラットフォーム撤去工事におけるク レーン船の作業期間短縮等を目的に, 3 重管の撤去作業を, 坑井の廃坑作業と同様に, 掘削リグで行うことに方針変更 された。3 重管撤去作業については, 帝石では全く経験の ない作業であるため, サービス会社の専門技術を利用する 必要があった。

同社は, ダウンホールモータを使用する切断方法により, 3 重管切断の時間短縮に成功したことをセールスポイント にしており, 事前ミーティングにおいても, ダウンホール モータの使用について強い提案があった。磐城沖プラット フォームのポンプラインについては, 洋上における経年劣 化が懸念されたため，ポンプレートおよび圧力に制限を加 えざるを得なかったものの, サービス会社の提案を採用し て, ロータリテーブルによる切断方法と共に, ダウンホー

*平成 20 年 6 月 11 日, 平成 20 年度石油技術協会春季講演会作井部門シン ポジウム「作井技術者の育成と HSEへの取り組み」で講演 This paper was presented at the 2008 JAPT Drilling Symposium entitled "Development of Human Resources and HSE Activities” held in Niigata, Japan, June 11, 2008. **帝国石油(侏) Teikoku Oil Co., Ltd.
ルモータによる切断方法も適用できるように，マッドポン プの 2 台並列運転ができるように配管を手直しした。

\section{3 重管撤去作業の内容}

\subsection{3 重管切断作業}

3 重管の切断方法には, 次のように 3 通りある。

(1) ケーシングに引つ張り力を掛けず, ロータリテーブ ルでドリルストリングを回転させて, 先端のケーシン グカッタにより 3 重管 $\left(10-3 / 4^{\prime \prime} \mathrm{CSG} \times 16^{\prime \prime} \mathrm{CSG} \times 24^{\prime \prime}\right.$ CSG (14 坑), 13-3/8"CSG × 18-5/8” CSG × 24" CSG (1 坑)) を切断する方法である。この方法は, ケーシングに引 つ張り力を掛けていないため, 切断時にケーシングカ ッタのナイフが抑留される危険がある（図 1)。

(2) ロータリテーブルでドリルストリングを回転させて切

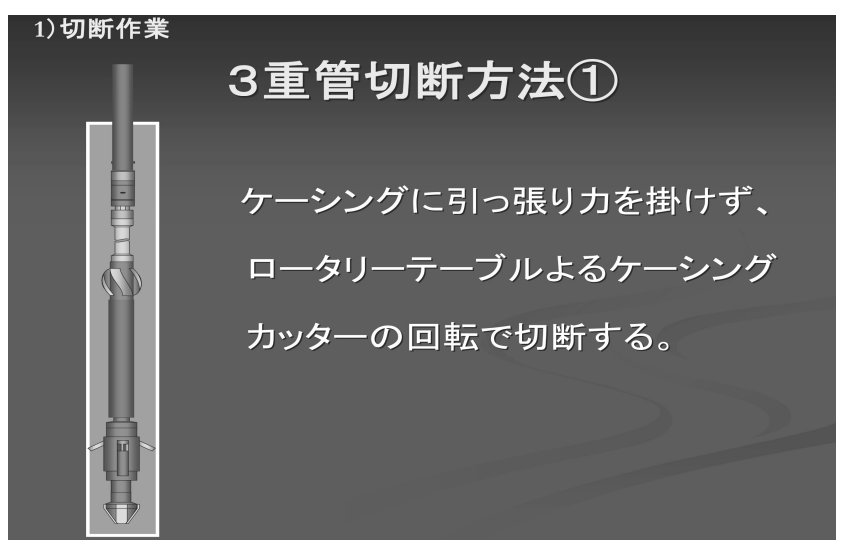

図 13 重管切断方法-1 


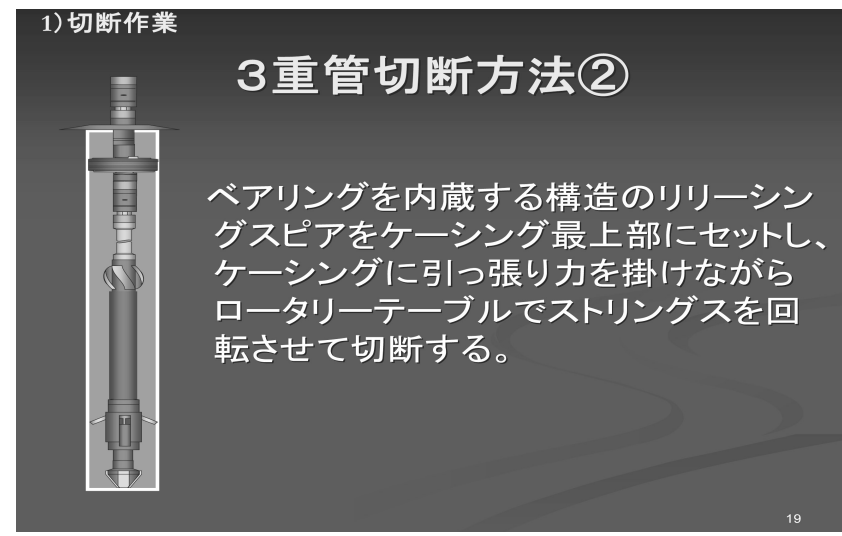

図 23 重管切断方法 -2

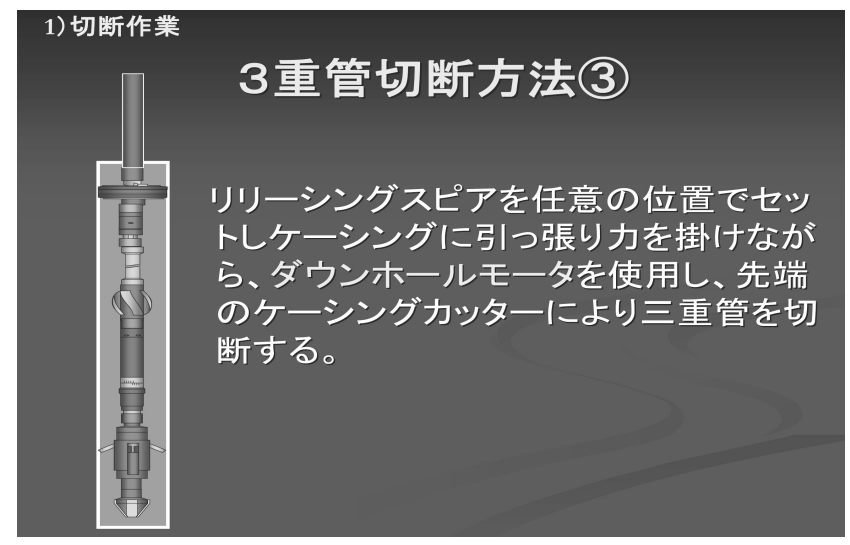

図 33 重管切断方法 -3

断する方法であるが，ベアリングを内蔵する構造のリ リーシングスピアをケーシング最上部にセットし，ケ ーシングに引つ張り力を掛けながら, 切断する方法で ある。この方法だと, 切断時にケーシングカッタのナ イフが抑留される危険はほとんどない。ただし, ベア リングを内蔵する構造であるため, 引つ張り耐力が小 さい（図 2)。

(3) リリーシングスピアを任意の位置でセットして，ケー シングに引つ張り力を掛けながら，スピア下に組み込 まれたダウンホールモータによるケーシングカッタの 回転で切断する方法である。ベアリングが付いていな いので，大きな引つ張り力が掛けられる。また，スピ アをセットする深度は自由に選択できる（図 3)。

いずれの方法も，海水循環によりケーシングカッ夕に圧 力を掛けてナイフを開かせ，ケーシング内面にナイフを押 しつけながら，回転させて切断する仕組みである。

なお，この海水循環を行うため，海水受けを製作してメ ザニンデッキに設置した。

\subsection{3 重管腰切と抜揚作業}

3 重管の腰切りとドリルフロアまでの抜揚は, リリーシ ングスピアにより行う。ドリルフロアまでの抜揚作業は, まずコンダクタを海底面まで抜き上げて， $5 \mathrm{~m}$ デッキにお いて 24 スパイダースリップをセットし，いつたんスピア を外してスタンドバックしてから，穴にグラベルを投下す る。次に，3 重管にスピアをセットし直し，ドリルフロア
まで抜揚, ドリルフロアにおいて 24 ”スパイダースリップ をセットし，スピアを外してスタンドバックする，という 流れである。

その後は, 1 坑のコンダクタ撤去作業終了まで, ドリル フロアとパイプラックにおける，抜揚，切断，倒管の繰 り返し作業になる。まず 3 重管に 6-1/2"の穴を開けて，6" ピンにより 3 重管を串刺しにし, 次にエレベータリンクか ら吊り下げられた厚さ 3 "のプレートを 6 "ピンに取り付け, 約 $12.5 \mathrm{~m}$ 抜揚して 24 ”スパイダースリップをセットする。 再び 6-1/2"の穴を開けて 6"ピンをセットする（図 4)。そし てケーシングソーにより 3 重管を切断し，パイプラックに 倒管する。

この抜揚, 切断, 倒管作業の繰り返しにより, 合計 15 本, 全長約 $183 \mathrm{~m}$ の 3 重管の抜揚作業が完了する（図 5)。

事前の検討において, 海底面下で切断された後の 3 重 管の重量は，3 重管の間隙を埋めるセメントも含めて最大 120 トンになると計算された。また，海底から 3 重管を抜

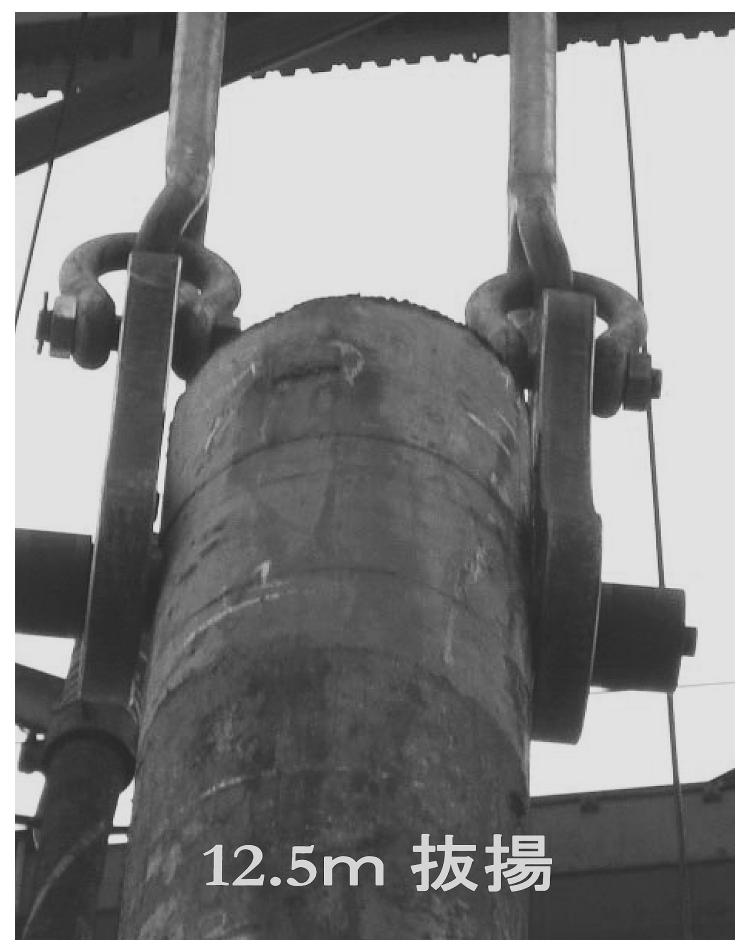

図 4 吊り具

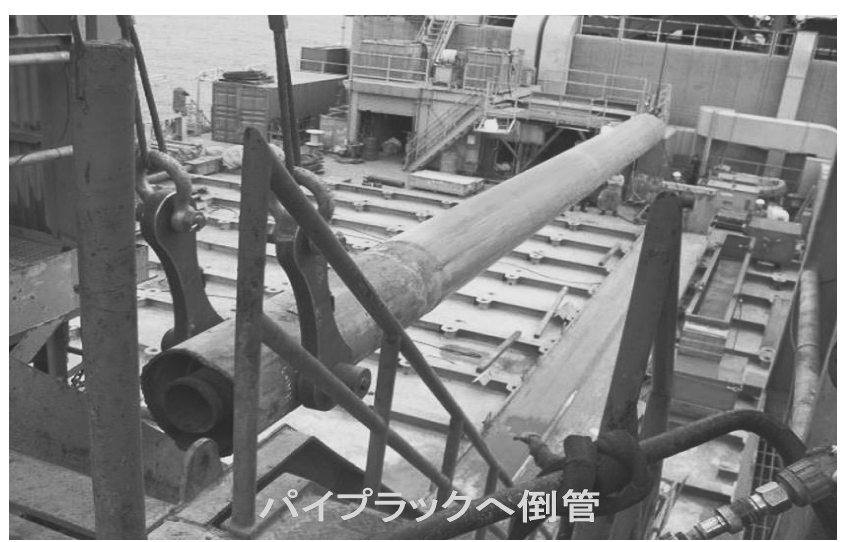

図 5 倒管作業 


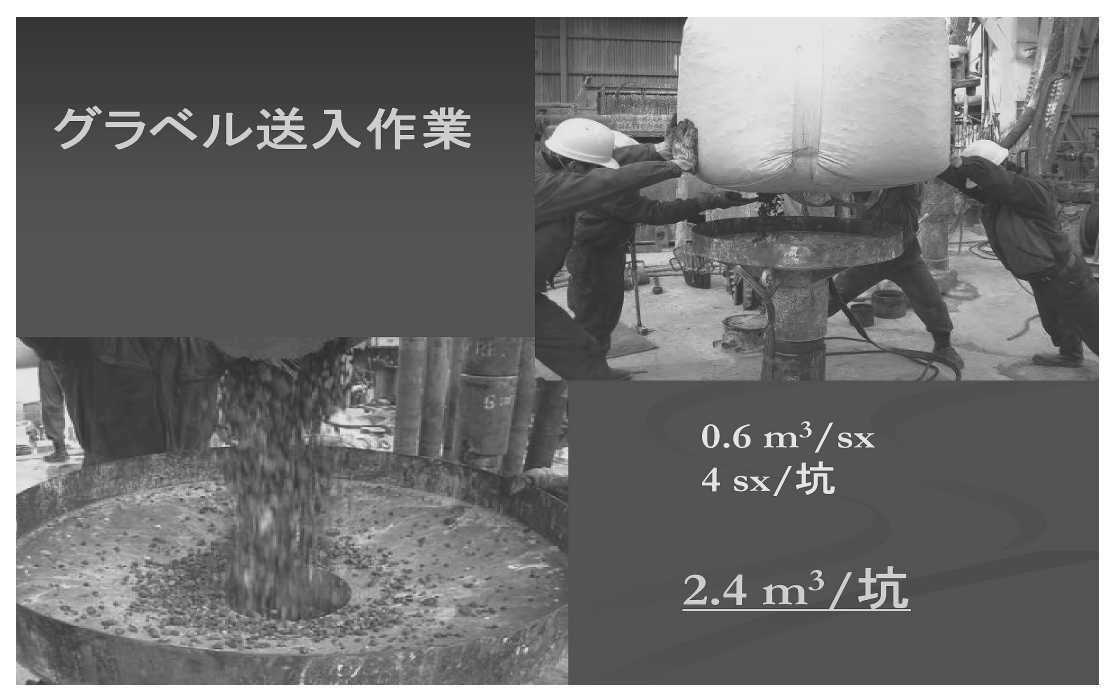

図 6 グラベル投下

き上げる際の腰切荷重については, 予想されるマリングロ ス（貝類等の海中付着生物）の抵抗力 $(20 \sim 60$ トン）と 土の粘着力（80トン）も加えると，220～260トンにもな ると計算された。

そのため, ドローワークスを始めとする掘削機械の吊り 上げ能力は, 110UE リグとして最大の 260 トンに調整した (ドリリングラインは 12 本綱)。

また, $5 \mathrm{~m}$ デッキの許容支持能力を 200 トン以上まで引 き上げるため, $\mathrm{H}$ 鋼による補強を行つた。

\subsection{3 重管抜揚後の穴の埋め立て作業}

3 重管を海底面より抜き上げると, 海底面に $24 "$ の穴が 残される。この穴は, 「廃坑後の坑口付近は埋め戻して原 状回復を図ること」という鉱山保安法の規定に従い，3 重 管を海底面まで抜き上げたところで, ドリルフロアから管 内にグラベルを投下して埋め立てることとした。

穴の埋め立て方法に関しては, サービス会社との事前協 議で, 砂を投下して埋め立てる方法や, ドリルパイプを使 用してプラグバックセメンチングする方法も検討したが, 仕事の速さと確実性, 海水污染の回避などを考慮し, グラ ベル（洗浄済みの細礫）投下により穴の埋め立てを行うこ とにした。そのため, グラベル投入用のホッパを製作し, ホッパ下には 3 重管への挿入管として, 廃坑作業で抜揚し た 9-5/8" CSG を利用した（図 6)。

\subsection{3 重管の排貝作業}

事前の検討において, 3 重管に付着した膨大な量のマリ ングロス（貝類などの海中付着生物）は，抜揚作業時に, 24 ”外径の 3 重管が約 25 ”内径のスロットの内側を通過する 際に，大きな障害になると予想された。スロットは，海底 面から $5 \mathrm{~m}$ デッキまでの間に合計 9 個あり, それらを通過 する際の抵抗力は 20 ～ 60 トンにもなると予測された。

また，マリングロスはサービス会社が提供する，約 $10,000 \mathrm{psi}$ の水圧により除去する仕組みのクリーナを $5 \mathrm{~m}$ デッキに設置し，排貝作業を行う計画とした。

\section{5 切断管の倒管作業}

ドリルフロアで約 $12.5 \mathrm{~m}$ の長さに切断された 3 重管を,
パイプラックに安全に倒管するため, サービス会社と入念 に作業方法の検討を行つた。この検討には多大な時間を費 やすことになったが，焦点は，3 重管にセットした 6"ピン に取り付けて使用する「吊り具」のデザインであった（図 7)。

使用する吊り具に対して要求される性能は, 次の 2 点で あつた。

(1) 抜揚作業における予想最大の吊り荷重（約 180 トン） をクリアしなければならないこと。

(2) 約 10 トンにもなる切断管を安全にパイプラック側に 引き寄せるためには，無理なくスイングできる機能が 吊り具に備えられていなければならないこと。

検討の結果, 厚さ 3 ”のプレート 2 枚をエレベータリン クで吊り下げて, これを 6 "ピンの両端に取り付けるという, サービス会社の最終案を採用することにした。

また, 倒管する 3 重管の断面方向の重心に偏りがあると, いったんパイプをドリルフロアに横置きして吊りワイヤを 付け足す時に, 予想外のパイプ回転が起こる危険性がある ため, 3 重管の回転防止装置を製作して対策した。

\section{3. 作業状況の概要}

\section{1 撤去作業工程}

3 重管は全部で 17 坑あり,この内 15 坑はガス採収井（14 坑は 10-3/4" CSG × $16^{\prime \prime}$ CSG × 24" CSG の 3 重管，また JB-2 の 1 坑だけは $13-3 / 8 ” C S G \times 18-5 / 8 ” C S G \times 24$ " CSGの 3 重管) で, 海底面下につながつたパイプである。また, 残りの 2 坑は $24 "$ CSG だけのスペアコンダクタパイプとカッティン グディスポーザルパイプで, 海面下約 $100 \mathrm{~m}$ まで吊り下げ られていた。

3 重管の撤去作業順序については, 14 坑と数の多い, 10-3/4" CSG × 16" CSG × 24” CSG の 3 重管から始めること とし, 14 坑の撤去作業を終了した後, 13-3/8" CSG × 18-5/8" $\mathrm{CSG} \times 24$ " CSG の 3 重管の JB-2 を撤去し, 最後にスペア コンダクタパイプとカッティングディスポーザルパイプを 撤去する作業工程とした。 


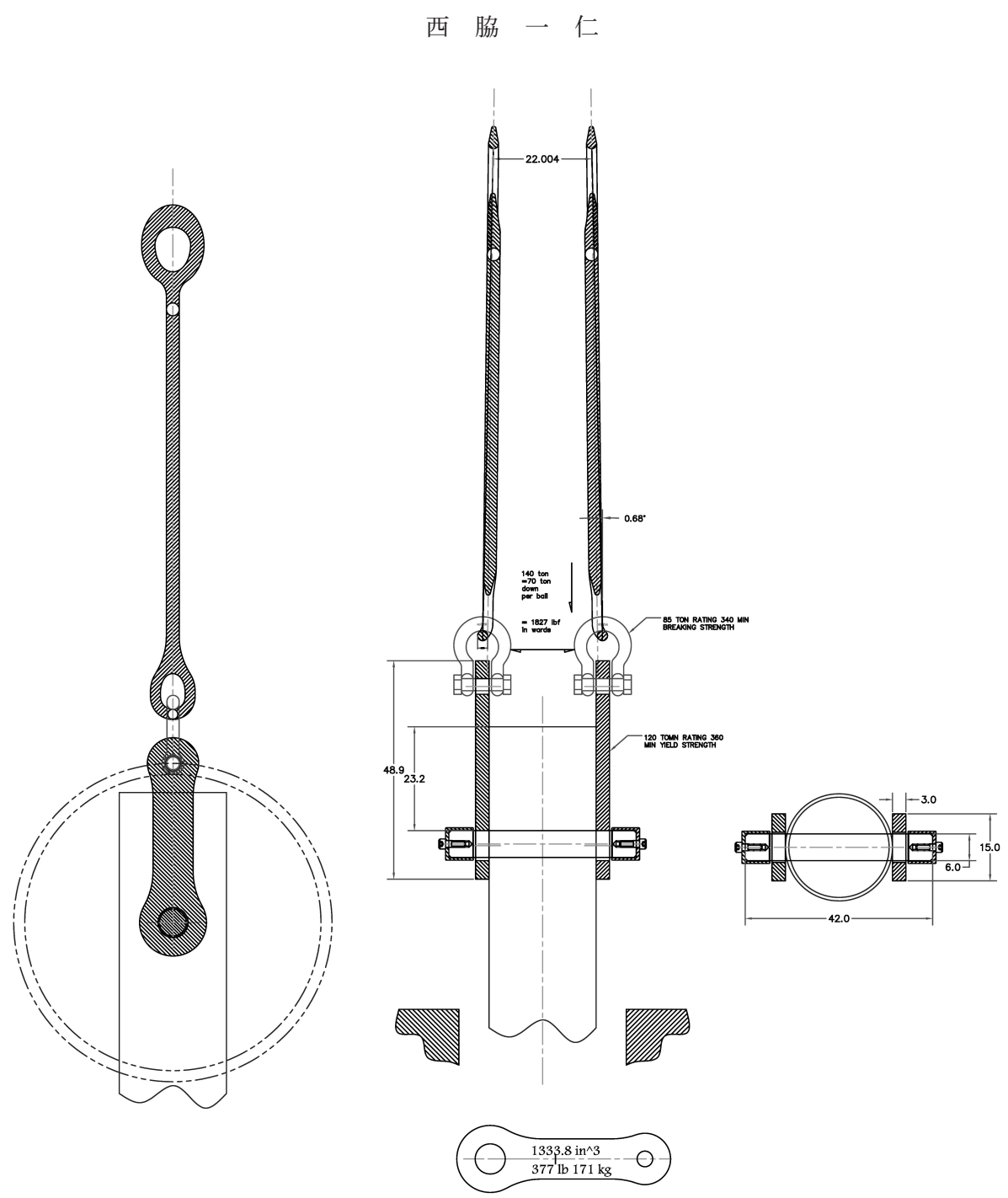

359

図 7 吊り具 デザイン

24" CSG だけの 2 坑については, 抜き上げるだけなので, 撤去済みのコンダクタパイプを吊り管として利用した。ま ず， $5 \mathrm{~m}$ デッキから吊り下げられているスペアコンダクタ パイプに, 吊り管を溶接して抜揚した。同様に, 最後のカッ ティングディスポーザルパイプも，メザニンデッキで吊り 管を溶接して抜揚した。

\subsection{3 重管の切断位置}

3 重管の切断位置は, 事前の原子力安全 - 保安院鉱山保 安課との確認内容に従い, 基本的に海底面下 $5 \mathrm{~m}$ 以深で切 断した。ただし，全 15 坑の内， 3 坑については，3 重管切 断作業中のケーシングカッタのナイフ脱落, およびリリー シングスピアのグラップル破損のため, 切断位置の変更を 余儀なくされ，わずかながらも計画の $5 \mathrm{~m}$ より浅い位置で の切断となつた。

\section{3 予想外の 3 重管抜揚}

廃坑作業時に, 全 15 坑井に対して実施した 10-3/4" CSG の CBL 測定結果から，多くの坑井においては 10-3/4" CSG 周囲のセメントボンドがあまり良くないと判断された。そ のため, ケーシングカッタで 10-3/4" CSG を切断して強引 すれば，かなりの割合で 10-3/4” CSG が抜けて来ると予想 された。そしてその場合には，10-3/4” CSG をすべて抜揚・ 倒管後, $16^{\prime \prime} \mathrm{CSG} \times 24^{\prime \prime} \mathrm{CSG}$ の 2 重管に対して, 切断・抜揚・
倒管の一連の作業を行う計画であつた。

ところが，CBL 測定の結果から，10-3/4" CSG が抜けて 来ることが最も確実視されていた，1 坑目の A-5 において 10-3/4"CSGが抜けて来ず, 3 重管のまま取り扱う作業となつ た。結果的には, 他の坑井もすべて，10-3/4" CSG が抜け て来ず, 3 重管のまま取り扱うこととなった。このことは, 少なからず作業時間の短縮に寄与したと考えられる。

\subsection{3 重管の切断}

3 重管撤去作業開始直後は, いろいろと試行錯誤があり, 多大な時間を費やしたが, 次第に作業方法が確立して行き, 5 坑目以降は, 当初計画よりも短い作業工程で, 3 重管撤 去作業を進めることができた。

当初は, サービス会社の提案を採用して, ダウンホー ルモータにより 3 重管を切断することを計画したが, ダウ ンホールモータの到着が遅れたため, 1 坑目においてはリ リーシングスピアで 10-3/4" CSG を強引して, ロータリテー ブルによる 3 重管切断を行った。

その後, 2 坑目から 4 坑目まで, ダウンホールモータに よる 3 重管切断をトライしたが, 結局は作業性および作業 時間短縮の面でメリットがなく，ロータリテーブルによる 3 重管切断方法に戻した。

なお， 5 坑目からはスピアによる切断作業中の 3 重管強 
引をやめた代わりに，始めにスピアにより 10-3/4" CSG に 130 トン以上の引つ張り力を掛けた状態で, $5 \mathrm{~m}$ デッキの 24"スパイダースリップをセットし（24" CSG の伸びなし）, それから 3 重管切断作業を行つた。

その結果, 5 坑目以降は極めて順調に作業が進むことに なつた。

ところで, ダウンホールモータによる切断作業が, 前評 判に反して効果を発揮しなかつたのはなぜなのか?

ポンプラインの能力が懸念されたため, ポンプレートお よび圧力を制限したことが，その一因になったのではない かと推測される。ポンプレートについては, 最大 $600 \mathrm{gpm}$ に制限したものの, この值はサービス会社の要求を，最低 限ながらも一応満たしたものである。一方でポンプ圧力に ついては，最大 $15 \mathrm{MPa}$ というポンプ圧力制限を設定せざ るを得なかったが，ダウンホールモータの能力を期待する 上では，厳しすぎる制限であったかも知れない。

3.53 重管腰切り時の土の粘着力とマリングロスの抵抗 力について

事前の検討では, 3 重管腰切り時の土の粘着力が 80 トン,
マリングロスの抵抗力が 20 ～ 60 トン，そして最大腰切り 荷重は $220 〜 260$ トンと予測されていた。だが，実際には そのような大きな腰切り荷重や抜揚作業中の引き上げ荷重 を経験することはなかつた。

その理由として, 腰切り荷重が予想より小さかったこと については，3 重管切断を完了した後も，しばらくの間海 水を送り続けて 3 重管周囲の洗掘を行ったことが功を奏し たと考えられる。また，爆薬切断でなくケーシングカッ夕 により切断したため, パイプの外側への変形がなかったこ とも，その一因と考えられる。

また，マリングロスについては，すべての 3 重管抜揚作 業に於いても大きな抵抗力は観察されなかった。

\section{6 無事故無災害を達成}

この大がかりな 3 重管撤去作業を実施するにあたり，い かに安全を確保しながら作業を遂行できるか，これが最大 のポイントであったが, 関係者全員の頑張りで, 最後まで 無事故無災害を貫くことができた。 